Crop Breeding and Applied Biotechnology S2: 15-24, 2012

Brazilian Society of Plant Breeding. Printed in Brazil

\title{
ARTICLE
}

\section{Contributions of the Instituto Agronômico (IAC) for plant breeding}

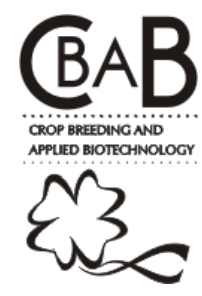

\author{
Sérgio Augusto Morais Carbonell ${ }^{1 *}$, Oliveiro Guerreiro Filho ${ }^{1}$ and Walter José Siqueira ${ }^{1}$
}

Received 15 September 2012

Accepted 03 October 2012

\begin{abstract}
The Instituto Agronômico (IAC) is a public institution that was founded in 1887 and has the mission of generating science and transferring technologies for the agricultural sector. This paper describes the main achievements in plant breeding and the use of IAC's cultivars. The impact in the agribusiness sector is demonstrated by the release of research results, especially in the form of products such as seeds and seedlings of 90 species. Out of these, 955 cultivars were properly described, characterized and made available to farmers (636 of them are registered in the National Cultivar Registration Service). Between 1932 and 2012 , IAC released an average of 12 cultivars per year, and in the period of 2003 to 2012, 185 cultivars were registered (one new cultivar every 20 days). The results can be evaluated by the representativeness of IAC in the use, customs and food preferences, among other possible measurements on the economic impact and/or return on investments made in the Institution.
\end{abstract}

Key words: Cultivars, cultivar registration, seeds and seedlings, technology, genetics, agribusiness.

\section{INTRODUCTION}

Among the practices employed in agriculture, few of them hold as much unanimity when it comes to their importance and beneficial results in relation to the use of improved cultivars. Plant breeding (PB) has contributed decisively to increase crop yield, to reduce costs and use of pesticides, to the best strategic use of inputs, such as fertilizers, and also to increase the technological or nutritional quality of the end-product.

Technological advances obtained by PB researches that are made in public and private institutions, located in the southeastern region of Brazil, can be described for several of the cultivated species. Numerous contributions of plant breeders have been released over the years in major public and private Brazilian institutions for teaching and research in agriculture.

Among the institutions that effectively contributed and continue working in the generation of new cultivars for the productive sector, the Instituto Agronômico (IAC) certainly deserves attention for its historical importance in the introduction and management of diverse germplasm, in human resources training and also in technology transfer through its cultivars all over its 125 years of existence. The story of IAC's success and technological achievements is extensively discussed in two publications (Castro and Moreira 2008, Furlani and Viégas 1993), which describe the pioneering, the research in plant breeding and the impact of IAC's cultivars on the agricultural scenario in Brazil and the world. These publications, along with IAC 72 Document (Almeida and Bidóia 2003), are the references for the preparation of this paper.

\section{THE INSTITUTO AGRONÔMICO AND ITS 125 ANNIVERSARY}

The Instituto Agronômico, based in Campinas, SP, Brazil, is a research institute of São Paulo's Agency for Agribusiness Technology (APTA), of the Secretariat of Agriculture and Supply of the State of São Paulo. Founded on June $27^{\text {th }}, 1887$, by Emperor D. Pedro II, it was named Imperial Agronomic Station of Campinas, and in 1892, it began to be controlled by the Government of the State of São Paulo. With the mission of generating and transferring science and technology for the agricultural business, IAC aims at the optimization of crop production systems and at the socio-economic development with environmental quality. Its performance also ensures food supply to the population and raw materials for industry, working for food safety and quality and competitiveness of products in the domestic and foreign markets.

At that time, coffee culture was established in the region, and due to the articulation of leaders from the coffee sector, D. Pedro II, by an imperial decree, created the Imperial

${ }^{1}$ Instituto Agronômico (IAC), CP 28, 13.012-970, Campinas, SP, Brazil. *E-mail: carbonel@iac.sp.gov.br 
Agricultural Station of Campinas in order to develop studies to support the culture. For nearly thirty years the studies were directed primarily to coffee. However, other species of increasing socioeconomic interest also received the attention of the few technicians who worked for IAC, who used test of adaptation to the producing regions of São Paulo.

The timid initiative resulted in the vigorous structure of research and development for agribusiness that is now the IAC. After the economic crisis of 1929, with the evolution of its technical staff and various restatements made in the institutional structure, it was intensified the studies of cultural techniques with cotton, corn, cassava, peanuts, sugar cane and many others. At this time, the breeding programs were also started, in scientific bases, resulting each year in new cultivars that started to be released, incorporating features such as high yield, resistance to diseases and pests, high protein content, and especially, high adaptation to the ecological conditions of the state.

\section{PLANT BREEDING AT IAC}

Initially, the different varieties that already existed, or the botanical species, were selected, tested and regionally made available to farmers through seeds, seedlings and buds, grown under controlled conditions.

Currently, most cultivars are the result of restless and careful work of researchers affiliated to various breeding programs that are developed in the institution. In some cases, depending on the species studied, the work ends after many years of testing, both in laboratories and in field trials, coming to a new cultivar with desirable characteristics, allowing producers to obtain higher profit, and consumers, a better physical and sensory quality.

One of the characteristics of the performance of the Instituto Agronômico is the public stance on the availability of the results of its researches, in the form of products, such as seeds, in services, such as laboratory analysis and, especially, through the transfer of technological information carried out through field days, publications, among others. The institution plays an important role as a state regulator in the area of selling seeds of varieties and hybrids, and most part of its activities is developed in partnership with farmers. The consequence is the high credibility of the institution, which makes its products and services be rapidly accepted and highly adopted, at both state and national levels.

Some of the examples listed below illustrate effectively the social-economic impacts caused in agricultural production, through the use of cultivars obtained by IAC crops, such as arabica coffee, herbaceous cotton, carioca beans, irrigated and upland rice, hybrid corn, sugar cane, potato, citrus, tropical soy, rubber tree, castor bean, guinea grass, fruits of temperate and tropical climates, vegetables, flowers, herbs, medicinal plants and green manures. IAC faithfully fulfilled its mission of generating and transferring knowledge and technology to the agribusiness in Sao Paulo and in Brazil, which can be verified by the data in Table 1, which shows that 90 plant species were effectively studied by the institution.

The survey that was made for 90 species, in this 125 th anniversary, which is celebrated on June $27^{\text {th }}, 2012$, shows the existence of no less than 955 cultivars, properly described, characterized and made available to farmers by IAC. Out of these, 636 cultivars were registered in the National Cultivar Registration Service (SNRC) of the Ministry of Agriculture, Livestock and Supply (MAPA). In the National Cultivar Protection Service (SNPC), 21 cultivars were protected (12 cultivars of sugar cane, 6 of bean, 1 of castor bean, 1 of coffee and 1 of pineapple).

In 80 years, between 1932 and 2012, IAC released an average of 12 cultivars per year, and in the period 2003 to 2012, 185 cultivars were registered in MAPA/RNC, i.e., a new cultivar every 20 days (Figure 1). Considering the third-degree polynomial distribution (cyclic) release of IAC cultivars (Figure 1), 175 new cultivars should be registered in the period from 2013 to 2022, i.e., an average of 18 cultivars per year or a new cultivar every 21 days. The $\mathrm{R}^{2}$ value of 0.86 that was obtained explains the total variance.

The consequences can be evaluated by the representativeness of the IAC agenda in Brazilian production, in the uses and customs, and in food preferences, among many other measurements that can be done on the impacts and / or economic return on investments made in the institution.

Detailed descriptions or summary of cultivars can be found in institutional publications, as Bragantia, $\mathrm{O}$ Agronômico, Scientific Bulletin Serie, Technical Bulletin Serie, IAC Documents, Circular, Annual Reports of the institution or its technical units, in conference proceedings and publications of other institutions, and also in dissemination of leaflets. Such cultivars are listed in IAC (www. iac.sp.gov.br/cultivaresIAC), as well as in IAC 72 Documents (Almeida and Bidóia 2003), containing the year of its availability, the outstanding feature and the publication where the description can be found. For 636 of them, it can be seen the registration number at MAPA-RNC, and for 21, at MAPA-SNPC (www.agricultura.gov.br).

The agronomic potential, the genetic pattern and product quality of the 955 IAC cultivars that were made available in these 125 years can be exemplified in many cultures, once 
Contributions of the Instituto Agronômico (IAC) for plant breeding

Table 1. Number of cultivars released/registered by the Instituto Agronômico, in its 125 years of scientific and technological research, separated by species

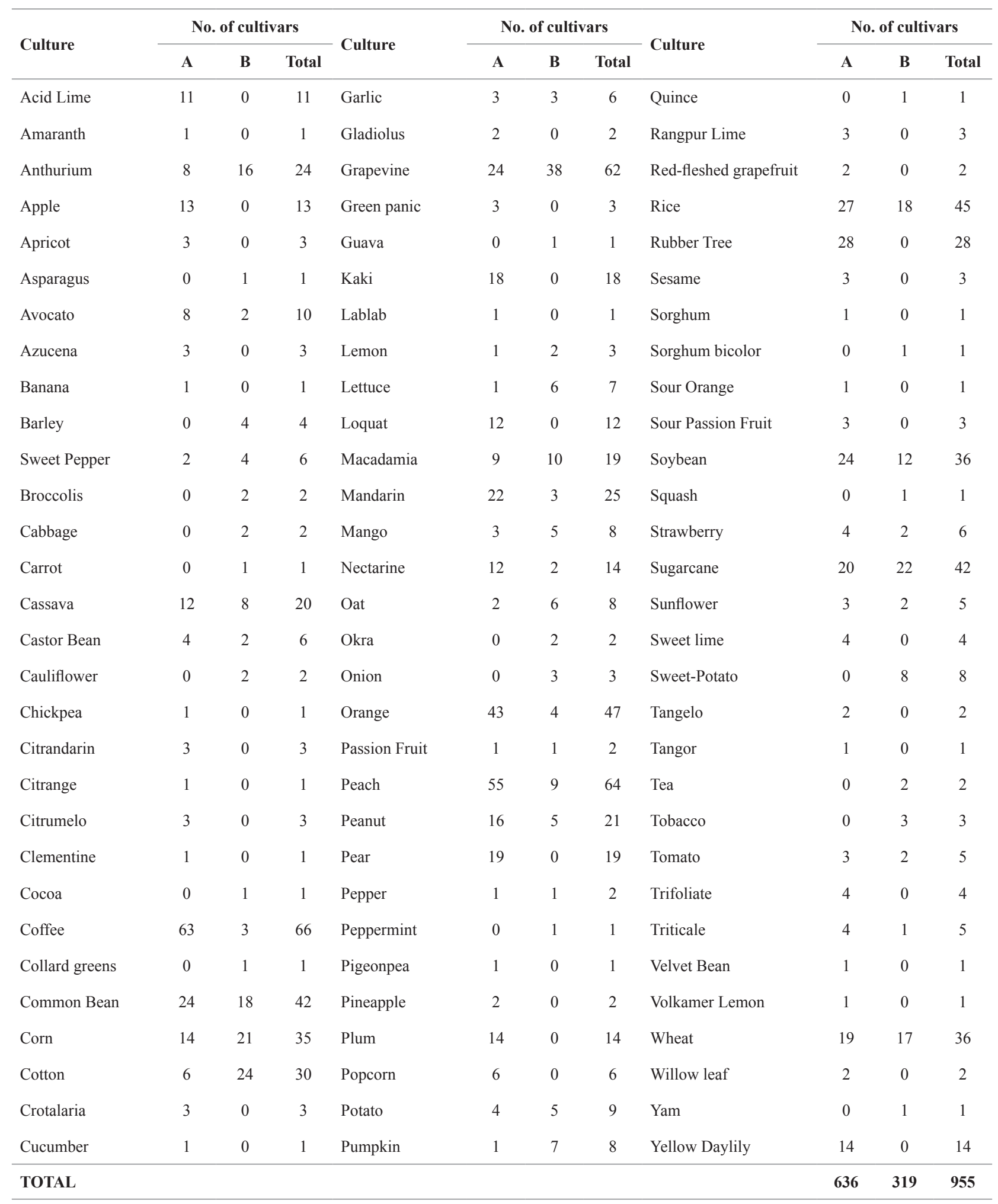

A: with RNC; B: without RNC 


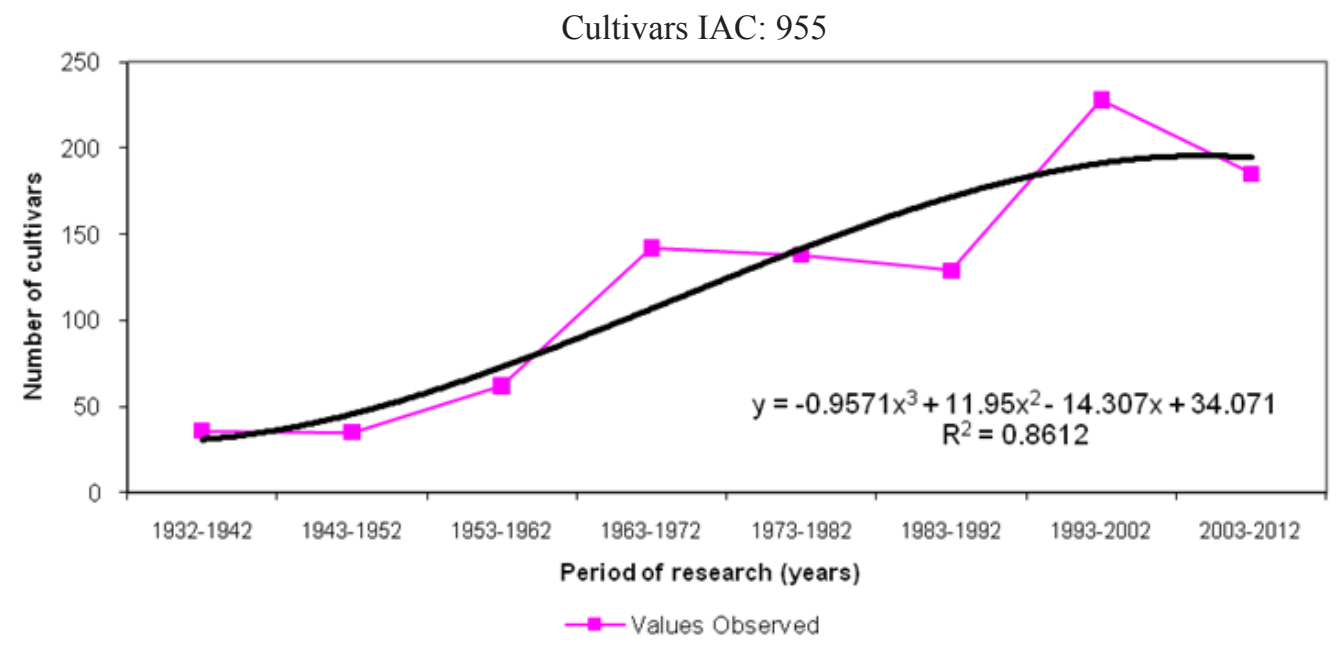

Figure 1. IAC cultivars released/registered, in periods of 10 years, that were done throughout its 125 years of scientific and technological research.

it is based on four pillars:

a) Updated and multidisciplinary range of research for obtaining new cultivars;

b) Extensive regional experimentation with studies that validate and discuss all these interactions with the environment, the productive sector and the consumer; c) Production systems for seeds and other propagules, ensuring their distribution and possible adoption;

d) Continuity of the work and the conviction of essential plant breeding work, which may not be unique, but it certainly will be the determinant of the future of this activity in this institution.

\section{THE SUCCESS OF THE RESEARCHES MADE AT IAC BASED ON DIVERSITY}

The strong and indispensable presence of agribusiness, agriculture and agricultural science in our lives, has been transferred by IAC through its cultivars all over its 125 years of existence. The achievements that make history in Brazilian agriculture can be exemplified and based on the needs and trends of the national agricultural sector.

\section{Coffee}

Coffee cultivars are the most significant examples of the importance of IAC in this segment. Improvement studies started in 1932, involving the species Coffea arabica. In 1950, coffee breeding research began, aiming tolerance/ resistance to rust, which is a landmark for Brazilian coffee, once it had started 20 years before the occurrence of the disease in Brazil. It is estimated that $90 \%$ of the nearly 4.3 million Arabica coffee grown in Brazil originates from IAC and even are the base of other important coffee producing countries. As an example, there are Caturra cultivar, selected in 1937; Mundo Novo cultivar, in 1952; and Catuaí Vermelho and Catuaí Amarelo cultivars, reselased in 1972, which changed the coffee production system, due to their short stature and high yield. The Apoatã rootstock, which is resistant to nematodes, provided the revitalization of coffee plantations in the Northwest of Sao Paulo, Minas Gerais and Paraná. All rust resistant cultivars were obtained in 1992 with the cultivars Icatu Vermelho and Icatu Amarelo. Later, in 2000, cultivars of short stature and rust resistant were registered, like Tupi and Obatã. Selections with multiple resistances to rust and nematodes, like IAC $125 \mathrm{RN}$, should be added, in 2012, to this extensive list.

Currently, genome researches have been incorporated into coffee breeding program, allowing selection and protection of IAC 045125 a naturally caffeine-free arabica coffee.

\section{Cotton}

Another historical example is related to cotton growing in the 1930s, which enabled economically the agriculture in southeastern Brazil, after the coffee crisis in 1929. In that year began the breeding program of cotton at IAC, in order to develop cultivars with multiple resistance to diseases, combining them with the characteristics of fiber. In 1932, IAC released IAC 7387 cultivar, and over the following years, new cultivars were made available in the market with these characteristics. Currently, IAC has a consolidated activity in breeding for resistance to multiple diseases and with bigger and better fiber quality, seeking to expand adaptation in other regions of Central Brazil and in naturally colored fiber types. 


\section{Rubber tree}

The rubber tree is another important and historic culture in IAC. In 1952, IAC introduced germplasm from Para and Bahia, Africa and Southeast Asia. At that time, the cultivar RR600, of IAC, was responsible for $60 \%$ of the national production of natural rubber. With new introductions of germplasm from Malaysia, Indonesia and Ivory Coast, breeding began in 1960, and from 1990, it started to emerge the first national clones. The breeding program at IAC rubber is unique in Brazil and has registered clones that present high yield and are more resistant to diseases. In 2011, 15 early clones of IAC 400 series were registered and made available for commercial production.

\section{Soybean}

The IAC soybean is important for the national agriculture. In the late twentieth century, IAC had already performed experiments with the culture, which until then, was exotic to Brazil. In 1889, the first studies were published, and in 1900 , the first seeds for testing and adaptation of cultivation were distributed to farmers.

Albura Cultivar, which resulted from the first selections at IAC, was the most cultivated until 1953 when it was replaced by Mogiana, Aliança and Yelnaldo cultivars. In the 1950's, it was released Araçatuba cultivar for human feeding, and Pelicano cultivar, for milling industry. In the 1970s, IAC indicated soybeans for the Brazilian Cerrado, demonstrating for the first time agronomic and economic viability of this species. From 1970 to 1975, IAC 2 and Santa Rosa cultivars were decisive for increasing soybean yield. IAC 5 cultivar is early and suitable to mechanical harvesting, whereas the IAC 6, IAC 7 and IAC 8 cultivars were good for cultivation in tropical regions in Brazil and in the African (Mozambique and Ivory Coast) continent. In 1980, IAC 100 was registered as one of the first commercial soybean cultivars with multiple resistance to chewing and sucking insects, which is a part of the major U.S. programs of crop breeding as parent and as resistance source.

\section{Rice}

Genetic improvement of rice began, at IAC, in the 1930 s, for irrigated and upland rice. In the 1960 s, IAC 1246 cultivar was released, which spread all over Brazil, opening new agricultural frontiers and occupying $60 \%$ of the national crop areas. In 1973, IAC 47 was released, which remained in culture for several years. In the 1980s, IAC 164 and IAC 165 caused great impact on the national upland rice production due to its high yield and to its long grain. IAC 201, released in the 1990s, introduced the fine long grain rice to the market, under upland rice cultivation, which remains in cultivation by farmers. Under irrigated conditions, IAC 105, which is resistant to rice blast, was released in 2007. In addition to these traditional types of rice, IAC innovated in 2006 with the registration of special types of rice to serve niche markets, being IAC 600, black grain rice, intended for the preparation of special dishes, IAC 500, as an aromatic type, IAC 400 for Japanese cuisine, and IAC 300 as a shrubby cultivar for risotto.

\section{Common Bean}

The importance of beans improvement by IAC can also be highlighted in various aspects related to disease resistance, grain technological quality, production stability and strengthening of beans trading companies. It started in 1932 and achieved its greatest success in 1970, with the release of "Carioca bean", a landmark of the culture, since it enabled a whole agronomic, business and consumption system in Brazil and abroad. "Carioca", or "Carioquinha", as it is popularly known, has provided stabilization between demand and supply in Brazil, offering good quality common bean throughout the year for the market. Moreover, its high acceptance by the consumers due to aspects of flavor and quick cooking, encouraged packing companies to invest in machinery and processes for a higher quality grain trading. The marketing and branding associated with the product were established and common bean began to be considered a big business, bringing income for the camp and for the trade. The breeding program at IAC has allowed the release of 42 cultivars, most of them from "carioca" group. Currently research institutions have been directed to obtain cultivars with high technological quality and nutritional grains. An example of this is IAC Alvorada, which was registered at MAPA/RNC in 2008, and became a reference of technology quality in Brazil due to the grains' fast cooking, pleasant taste and resistance to browning. In 2011 it was registered IAC Formoso, which presents high yield, resistance to foliar and soil diseases, besides containing high levels of isoflavones, which is an important phytoestrogen in controlling coronary heart disease, it combats free radicals and replaces hormones in women. In 2012, to meet the demand for early cultivars of common bean, IAC registered IAC Imperador cultivar.

\section{Corn}

Corn breeding, at IAC, started in the same period as coffee studies did, in 1932, with the first work with hybrid corn in Brazil. In 1939, it was released the first Brazilian double hybrid. In 1970, IAC corn predominated in corn crops in Brazil, and the hybrid HMD-7974 was sown for ten years. 
IAC also introduced the brachytic gene in its cultivars in order to reduce the size of plants for mechanized harvesting. Along the same lines, hybrids of popcorn were developed, being IAC 112, originated from researches that began in 1987, considered the best popcorn hybrid from Brazil. IAC 125 also achieved great success due to its resistance to soil aluminum toxicity.

\section{Winter cereals}

The breeding of winter cereals, such as wheat, started in 1937, being IAC 5 considered the most widespread in the 1970s. In 1980, IAC 24 was released, being the first variety of low stature that is tolerant to aluminum, which is still in use, and allowed a yield increase of $800 \mathrm{~kg} \mathrm{ha}^{-1}$ to $3000 \mathrm{~kg}$ $\mathrm{ha}^{-1}$. Moreover, the grains of IAC 24 produce high quality flour for bread, cakes and cookies making. In 2008 and 2010, IAC registered, respectively, IAC 381 and IAC 385 Kuara Monjave, two short height cultivars, which present excellent quality of flour to meet the rigid requirements of marketing in Brazil.

Breeding for winter cereals was also directed to obtain cultivars of triticale, with emphasis on IAC 5, obtained in 1970, which is still cultivated because of its quality of hardiness and yield. Oats can be represented by IAC 7, a cultivar that shows excellent quality for the food industry of flour and flakes.

\section{Peanut}

The peanut crop deserves attention once it enables the production of edible oil and grain for confectionery. Growing peanuts in São Paulo began in the 1920s, using technology generated by IAC and it had its peak in the 1950 s, extending to the 70's. The most widespread cultivar was Tatu Vermelho, which was later replaced by IAC Tatu ST. In 1980, the improvement of peanut began at IAC through intraspecific hybridization, being the IAC Caiapó, registered in 1996, the first Runner cultivar in Brazil. In 2001, IAC released the cultivar IAC 886 Runner, whose product (fresh beans) met the specifications for the international market, a segment that the chain of production started to explore ever since. In 2009, IAC innovated with the registration of IAC 503 and IAC 505, which present high yield of oil high in oleic acid, a characteristic that gives greater stability in keeping the product on shelves. Currently the program increased the breeding program with interspecific hybrids for resistance to pests and diseases. Today, IAC cultivars are widespread in major producing regions of São Paulo and in other regions of Brazil, where the culture is expanding.

\section{Cassava}

The economic and social development of several regions had strong influence from IAC cassava cultivars. The first research with cassava at IAC is dated from 1899, and in the 1910s and 20s, the main crop management techniques were described. The improvement was initiated in the 1940s, with Branca Santa Catarina cultivar, which was widely planted between 1950 and 1970, occupying 200 hectares, and making Brazil a potential starch exporter after the II World War due to the lack of raw materials; today this cultivar is part of the genealogy of the main varieties developed by IITA (International Institute of Tropical Agriculture), in Africa. IAC 24-2 Mantiqueira also deserves attention for its spread in several countries of Latin America and the Caribbean, once it was considered the best cultivar in evaluations done by CIAT (International Center for Tropical Agriculture). In the 1990s, IAC 576-70 table cultivar, which is rich in vitamin $\mathrm{A}$ and carotenoids and resistant to diseases, revolutionized the market, occupying almost $100 \%$ of the cultivated area in Brazil. It boosted exports of sweet cassava to Europe and the industry of frozen and processed foods. IAC 12 was also remarkable for the development of the culture in Cerrado due to its high content of dry matter. Currently, researches are being developed in order to produce flour with higher levels of carotenoids and vitamin A, in addition to enabling the use as raw material for ethanol production from starch.

\section{Potato and Sweet Potato}

Being one of the main foods of the Brazilian population, the potato had IAC 2 as its first cultivar, known by the farmers as Aracy, with greater resistance to potato leafroll virus. In organic agriculture, Itararé IAC 5986 cultivar is currently the most sought after by farmers. Apuã and Aracy ruiva cultivars also deserve attention, and the last one is a mutation of the Aracy for enlongate tuber. Also, the sweet potato cultivars Monalisa IAC 66-177 and IAC 2-71 are the most important selections grown in São Paulo. The studies with sweet potato have been widening, getting excellent prospects for both fresh consumption and for biodiesel production.

\section{Vegetables}

The horticulture has its history based on the pioneering work of IAC. Research in the area initiated in 1927 and consolidated in 1937. There are countless examples of IAC cultivars that revolutionized the cultivation of vegetables in Brazil and Latin America. As an example, it can be cited Lavinia garlic, Ramoso broccoli, Sabaúna cabbage, Campinas 2 okra, and Guarani and Campinas strawberries - this last one was market leader from 1960 until 1990 and is grown until today. 
Santa Cruz tomato cultivar (bilocular and elongated fruits), IAC Angela Gigante 5100 (staked or trellised type), developed by IAC, accounted for $70-75 \%$ of the planted area in the country in the 1990s. In 1995 it was selected IAC Santa Clara cultivar (Angela Gigante x Duke Hybrid), which produces larger fruit, weighing around 200g, also are highly influential in State and National tomato production. This cultivar with larger fruit, with an average of $200 \mathrm{~g}$, more rounded (trilocular or more) foresaw the current trend of the market in Brazil with the release of long life tomatoes by private industries. IAC tomato cultivars presented resistance to Fusarium wilt (races I and II), Verticillium wilt, gray leaf spot, bacterial canker and to the viruses Y, TOYTV and TBLYV.

The breeding program of butter lettuce, which presents a soft loose head of tender shiny leaves, started in 1968. In 1973, IAC Brazil 48 cultivar was released, which generated "Brazil Series" released by the Instituto Agronômico. Cultivars were practically pioneers, because they had resistance to lettuce mosaic virus and were adapted to the summer planting. This series presented the following releases: IAC Brasil 202, 221 (1977), Brasil 303, 304, 311 (1979) gathering qualities of head and leaves, which is a preference for producers and consumers from Sao Paulo, and resistance to viruses, including Tomato spotted wilt, and to the heat. Other commercial versions were released by the private sector using these cultivars.

In relation to bell pepper and pepper, in 1968 it was released the pioneer Agronômico 8 cultivar, which presents multiple resistance to several PVY virus races or strains, opening up a new series of releases called "Agronômico". In 1971, the best pepper cultivars, which present multiple resistance to PVY, were released: Agronômico 9 and Agronômico10G, being cultivated for decades, and were even used by the public and private sectors as sources of resistance in several countries. From 1972 to 1990 the peppers Agronômico 11, 4, 13, IAC Ubatuba and IAC Cambucci were released, being the last one resistant to two spotted spider mite and broad mite.

\section{Ornamental species}

Floriculture in IAC began in 1940 with studies about annual flowers, orchids and roses. In 1948, the organization of germplasm bank of ornamental species started, with the inclusion of several trees and palms, heliconias, amaryllis, anthurium and alstroemeria, among others, that supported all the improvement work at IAC. In the 1980s, IAC's studies caused an important impact in Brazilian floriculture with researches on tropical ornamental plants. The release of cultivars of anthurium, as IAC Astral, and heliconias, among others, showed that IAC is as an important reference for studies about tropical ornamental plants. Currently the institution is a reference in research in the North and Northeast of Brazil and also in several Latin American countries. The cultivars of Astral anthurium, Cananéia and Eidibel became the most widely cultivated ornamental plants in Brazil.

\section{Castor bean and other oilseeds}

At IAC, research on castor bean started in 1936 with basic studies of management and breeding. The improvement of the species was based on achieving cultivars with high yield, short stature, indehiscent racemi and high oil content. In 1974, IAC released Guarani cultivar, still cultivated in several regions of Brazil, and it is the bases for government programs for biodiesel production. Modern cultivars, such as IAC 2028, released in 2007, which presents short stature, indehiscent racemi, high yield and high cultivation adaptation, has increased the production of raw material to produce biodiesel and also provided income generation and employment in poor regions in the Northeast Brazil.

The first selections of sesame grown in Brazil were made by IAC after 1936, coming from India, Bulgaria and then Venezuela. Cultivars with high yield potential as IAC Ouro, IAC China and IAC Guatemala were released in the 1980s, being especially recommended for cultivation in the Southeast and Midwest.

The first sunflower cultivar was IAC Uruguay, released by IAC in 1962, which presents a tall-stature. In 2005, aiming greater yield, IAC released IAC Iarama, which has short cycle, uniformity of grains and it is a short height cultivar.

\section{Tropical climate fruitculture}

The first researches with fruit at IAC began at the creation of the institution, in 1838, with records of pest and disease control. In 1921, several experimental fields of avocado, greapvine, temperate fruits, mango, jabuticaba tree, pineapple, banana, guava and other fruits from Myrtaceae family were installed in Santa Elisa Station, in Campinas. Banana improvement at IAC, which had its landmark with the release of IAC Nanicão-2001, and is resistant to yellow sigatoka, contributed to the sustainable management of fruit in the country and for the development of poor regions like the Vale do Ribeira region, São Paulo state.

After IAC Gomo-de-Mel was released, in 2005, the pineapple opened new prospects for niche consumer markets by presenting a small, rounded fruit for individual consumption (fruitlets) and excellent pulp quality. Release in 2010, IAC Fantástico cultivar (registered and protected by MAPA/ RNC), which is resistant to fusarium wilt and presents an 
excellent quality of pulp and juice, has contributed to the expansion of cultivation in Brazil. Mango improvement got in 1989 IAC 100 cultivar, which is resistant to mango drough; Espada Vermelha cultivar, which is resistant to fruit fly; and several rootstocks which are resistant to diseases. In the culture of passion fruit, IAC has provided, since 1990, major technological advances with cultivars from 270 serie, especially IAC 273 and IAC 275. With this material, the state of São Paulo gained prominence nationally and globally. In 2007, IAC Paulista innovated to produce purple colered passion fruit.

\section{Sub-tropical and temperate climate fruiticulture}

The improvement of grapes, peaches, nectarines, plum, apple, persimmon, among others increased after 1942, with the creation of sections of Temperate Fruit and Viticulture at IAC. In this work, hundreds of cultivars were registered, being all of them characterized by presenting very low chill hours requirement, resistance to diseases and pests, and high fruit quality. All of this gave wide adoption of IAC cultivars, increasing planting in new areas, and developing markets that are currently recognized as important centers for fruit, as Jundiaí, San Roque, Monte Alegre do Sul, Jales, Limeira and Capão Bonito, in the State of São Paulo.

Grape cultivars had attention in national viniculture, as IAC 138-22 for wine production. Among the varieties of table grape, IAC Juliana, which presents muscatel flavor, was another option for the farmers, in 2001, to replace Niagara Rosada. The rootstocks of IAC are currently used in most wine regions of Brazil. In northeastern Brazil, IAC 572 is the support base of winemaking in the Vale do São Francisco, whose production serves the domestic and even overseas markets.

In 1999, seedless table grapes were registered in MAPARNC, cultivars IAC 514-6 Maria and IAC 871-13 A Dona, presenting good taste, dark pink berries, high and medium productivity, respectively. IAC 871-41 Patricia presents large bunches, black berry, excellent taste, due to the high Brix and low acidity, being resistant to berry splitting, and planted in large scale in the northeast. IAC 842-4v Piratininga cultivar became the second most widely planted cultivar in the Vale do São Francisco.

Among peaches, Talismã cultivar deserves attention. It was released in 1960 by IAC, which came to occupy more than $80 \%$ of the cultivated area in the State of São Paulo. Table cultivars and cultivars for industry were released in the 1970s, highlighting Tutu, Relíquia, Cristal, Natal and Biuti. In 1980, the new cultivars Jóia, Delicioso Precoce, Ouromel, Dourado, Aurora and Tropical boosted trade by their high yield, early maturity and quality of yellow or red pulp. Recently, Douradão cultivar occupies a prominent position in agriculture in the State of Sao Paulo. In 1980, IAC released Rosalina, Josefina and Centenária nectarine cultivars, which are widely grown in São Paulo.

In relation to plums, the cultivar Carmesim, released in 1973, with early maturing, high yielding, outstanding sensory characteristics and low chilling requirement, expanded rapidly in Sao Paulo and neighboring states. Centenária cultivar, on the other hand, provided the expansion of harvest due to late ripening of the fruit.

About $70 \%$ of the current Brazilian Macadamia area consists of Hawaiian cultivars introduced by IAC in 1940 and adapted to our growing conditions. IAC4-20 and IAC 1-21 cultivars were derived from this germplasm, which were released in the 1970s, whereas IAC 4-12 B and AIC Campinas $\mathrm{B}$ were released in the early $80 \mathrm{~s}$. Together, they represent approximately $30 \%$ of the cultivated area in the country.

\section{Citrus}

The most important contributions of scientific research for the Brazilian citrus are undoubtedly developed by the Instituto Agronômico. In the early 40s, IAC began to recommend Cravo lime as a rootstock for installing new orange groves, depending on the resistance presented to citrus tristeza virus. High yielding nucellar clones of Baianinha, Hamlin, Pêra and Barão cultivars that were free of diseasecausing viruses as exocortis, psorosis and xylosporosis, were distributed by the institution in the mid 50s.

The Brazilian citriculture lays in a wide range of scion cultivars selected by IAC, like Pera clonal cultivar and preimmunized Valencia, Westin oranges, Rubi, Hamlim, Baianinha IAC-48, Baianinha IAC-79, Baianinha IAC-89, Natal nucellar clone; Mexerica-do-Rio early maturing mandarin, Mexericas-do-Rio late maturing mandarin, the Murcott tangor, as well as the acid limes Galego IAC-2 and Taiti IAC-5, among others. In 2007, IAC released cultivars of seedless Clementina Nules IAC 1742, Nova IAC 1583 and Ortanique IAC 554, which are characterized by presenting intense color and flavor, which makes them the option to export to the European market. It was released Laranja Sanguínea de Manbuca, which presents a reddish pulp due to its high lycopene content $(200 \%$ over Pêra sweet orange). Lycopene is known as cancer preventive agent by protecting cells from the action of free radicals.

\section{Sugarcane}

The Instituto Agronômico started its first studies in management of sugarcane in 1892. The first researches involv- 
ing breeding for resistance to gummosis and mosaic in the culture started in 1930, using cultivars introduced from other countries. The first cultivars obtained in the country, IAC 48-65, IAC 50-134, 51-205 and IAC IAC 52-150, would be released only in the 40s and 50s. In 1990, it was created the Sugarcane Program at IAC, which intensified studies with genetic improvement through partnerships with more than 70 corporations throughout Brazil. Between 1997 and 2002, IAC registered nine cultivars of sugarcane at MAPA/RNC, one of them is IAC 86-2480, which is exclusively for forage, whose success exceeded the border of São Paulo, expanding to most important national regions of dairy and beef cattle. In 2005, it was registered five more sugarcane cultivars that present high yield, aiming government programs to produce ethanol.

\section{Aromatic and medicinal plants}

After water, the tea (Camellia sinensis - Family Theaceae) is the most consumed beverage in the world. The Instituto Agronômico, in Campinas developed in 1968 two varieties of tea, IAC 250 and IAC 259, which today are planted in the Vale do Ribeira, the main producing region of the State of São Paulo.

A variety of IAC 701 peppermint was responsible for making Brazil become the world's largest producer of menthol until the advent of synthetic menthol.

Lippia alba, a dicotyledon of Verbenaceae family, is a shrubby species, aromatic and medicinal, native to South America and of a very popular use in the Brazilian pharmacopoeia. It has numerous chemical compounds in the composition of its essential oils, making it one of the main species for industrial use in the areas of health, perfumery, cosmetics, natural pesticides, veterinary, environmental fragrance and candy.

The Instituto Agronômico released for the industrial sector, in 2011, forty-two types of fragrances (aroma bank), from unprecedented Lippia alba clones that were obtained by selection between and within half-sib families and sibs. It is expected to open new market niches with the added value to this new agricultural option, which is usual in family farming.

\section{Green manures}

In Brazil, the cultivation of Crotalaria juncea $\mathrm{L}$. is intended in particular for organic soil composting, such as green manure, and also the production of fibers for high quality paper manufacturing. IAC KR-1 and IAC 1 , released in 1984 by IAC, and both resistant to wilt caused by Ceratocystis fimbriata, are the only available and marketed in Brazil

In 1989, IAC released IAC-Fava Larga de gandu, a selection of long cycle, which presents high yield and it is drought resistant and adapted to our soil and climatic diverse regions.

\section{FINAL REMARKS}

Plant breeding and management of plant genetic resources at the Instituto Agronômico have a set of disciplines, techniques, processes and methods of support covering plant genetics, cytogenetics, classical and molecular, in vitro culture of plant tissues, molecular markers, isozyme and morphological, phytochemical, botany, morphology and genetic engineering.

In the coming years, besides continuing the current projects, the Instituto Agronômico will prioritize the development of innovative research in the area of genetic improvement. There will be greater emphasis on research with native species, semi or non-domesticated fruit trees, ornamental, aromatic, medicinal and with potential for bioenergy production.

Researches related to introgression of genes into elite cultivars will receive attention, especially in relation to tolerance to drought and heat, as well as those aiming at the production of functional food (nutraceutical), selection of cultivars with photosynthetic efficiency and nutrient absorption with responsiveness to increments technology applied to crops. Studies using beneficial microorganisms (rhizosphere and endophytic) with superior genotypes selected in the genetic improvement will be emphasized at the Instituto Agronômico. Research projects in the field of epigenetics (frequency, types, stability and inheritance) in order to obtain epigenetic cultivars began in 2012. Thus, the Instituto Agronômico will continue, through scientific and technological studies generated by its team of scientists, to promote social inclusion of products with higher added value and better suited to exploitation by supporting agricultural sector production chains and helping to create others. 


\section{Contribuições do Instituto Agronômico (IAC) para o melhoramento de plantas}

Resumo - O Instituto Agronômico (IAC) é a uma instituição pública de 125 anos com missão de gerar ciência e transferir tecnologias para o setor agrícola. Neste artigo são descritas as principais conquistas do melhoramento de plantas e adoção das cultivares IAC. O impacto em setores do agronegócio é demonstrado pela disponibilização dos resultados de pesquisas, especialmente na forma de produtos, como sementes e mudas de 90 espécies. Destas, 955 cultivares foram devidamente descritas, caracterizadas e colocadas à disposição de agricultores (636 cultivares registradas no RNC/MAPA). Entre 1932 e 2012, o IAC disponibilizou uma média de 12 cultivares por ano, sendo que no periodo de 2003 a 2012, 185 cultivares foram registradas (uma nova cultivar a cada 20 dias). Os reflexos desta ação podem ser avaliados pela representatividade das cultivares IAC nos usos, costumes e preferências alimentares, dentre outras possíveis aferições sobre os impactos elou retorno econômico dos investimentos aplicados na Instituição.

Palavras-chave: Cultivares, registro de cultivares, sementes e mudas, tecnologia, genética, agronegócio.

\section{REFERENCES}

Almeida LDA and Bidóia ED (2003) Cultivares IAC. Instituto Agronômico, Campinas, 43p. (Documentos IAC, 72).

Castro OM and Moreira AC (Org.) (2008) Ciência da terra: o Instituto
Agronômico e a pesquisa em benefício da qualidade de vida. Instituto Agronômico, Campinas, 160p.

Furlani AMC and Viégas GP(Ed.) (1993) O melhoramento de plantas no Instituto Agronômico. Vol. 1, Instituto Agronômico, Campinas, 524p. 